\title{
PREF ACE
}

In June, 1969-while I was conducting field research for this study-Peru's governing military junta announced an extensive landreform program designed to distribute hacienda lands to needy villagers and peons. Consequently, the socioeconomic conditions of the Peruvian highlands that are described in the early portions of this book have been undergoing dramatic change. The land-tenure arrangements and hacienda domination that stimulated peasant mobilization in 1963-1964 seem to be disappearing. This book's concluding chapter, which serves as a postscript to my earlier research, analyzes the first three years of the current land-reform program. Events since 1969 reinforce my earlier conviction that rural unrest and peasant political mobilization may continue despite the government's land-redistribution policies. Consequently, the issues of peasant mobilization discussed here are still relevant in Peru and other Latin American nations.

Anyone who has ever done research abroad knows that a scholar working in a foreign country can be successful only if he receives the cooperation and support of many persons. My work in Lima and in the villages of the Peruvian sierra (highlands) was exciting but difficult. Before leaving the United States, I was warned that Peruvian peasants and intellectuals would be very suspicious of my investigation.

In selecting students to administer my survey, I asked each applicant to consider carefully whether he wished to do such work with a "gringo." After I had picked my research assistants, I informed them that they could eliminate any items from my questionnaire that they considered objectionable or that they did not feel com- 
fortable asking. None of them wished to remove any questions. In fact, they added one or two inquiries that I had considered too sensitive. Village leaders were also told that they should only answer those parts of my questionnaire that they wished to. Here again, my informants surprised me with their candor in expressing political opinions. In only two of the forty-three peasant communities that I visited did village leaders refuse to submit to the questionnaire. Although a few peasant leaders and urban political activists were too suspicious to work with me, I was impressed by the kindness and cooperation of most Peruvians whom I approached.

I could not possibly thank all the persons by name who were so helpful in assisting me. My deepest appreciation goes to the peasants, journalists, lawyers, government officials, students, and political prisoners who patiently and candidly answered my questions. I shall never forget the village peasants who opened their homes to me and to my research assistants and who shared their scarce food with us. I am also grateful to Dr. Julio Cotler (of the Instituto de Estudios Peruanos) and Dr. Fritz Wils (then of Lima's Universidad Católica) for helping me adapt my research plans to Peru's particular conditions and for giving me invaluable advice in many areas.

In the United States, Gerrit Huizer (International Labor Organization), Maurice Zeitlin (the University of Wisconsin), and Lisa North (York University) helped me with their suggestions and criticisms. Brian Silver (Florida State University), Jorge Dandler (Universidad Católica), and Donald McCrone (University of Iowa) read parts of the manuscript and offered valuable comments. I am particularly grateful to Charles Anderson of the University of Wisconsin's Political Science Department. As my graduate academic adviser and as a friend, he contributed greatly to this particular research and to my general understanding of Latin American politics. Needless to say, I bear sole responsibility for the contents of this study and for any errors of judgment or fact that it may contain.

I am indebted to William F. Whyte (New York School of Labor and Industrial Relations), Dr. Héctor Martínez (the Instituto Indigenista of Peru's Labor Ministry), and the Dirección Nacional de Estadística y Censos for graciously giving me access to unpublished data that they had gathered on the Peruvian sierra.

I would also like to thank Mrs. Marilyn Henry, who showed great 
patience in typing this manuscript; Susan Yáñez, who helped as a research assistant; Robert Albrecht, who contributed to the final editing; and Don Temple (University of Wisconsin-Milwaukee), who drew the maps.

Support for my field research came from the University of Wisconsin's Ibero-American Studies Committee with funds provided by the Ford Foundation. The University of Wisconsin-Milwaukee's Latin American Center provided support to reduce my teaching load and permit the completion of this manuscript.

My greatest debts are to Arturo Igreda, Julio César Palacios, Romigio Poma García, and Humberto Tocre-Peruvian University students who helped me conduct my village surveys and who served as warm hosts and guides in their native regions of the highlands; and, most of all, to my wife, Nancy, who cheerfully experienced with me the hardships of life in the Peruvian rural highlands, who aided me throughout my research, and who provided the intellectual insights of a historian concerned with many of the same issues in her own research. 
THIS PAGE INTENTIONALLY LEFT BLANK 